Research Article

\title{
The Biocidal Investigation of Various Extracts of Pleurotus eryngii Cultivated on a Substrate Supplemented with Berberis lycium
}

\author{
Shahida Sabir ${ }^{1}$, Anwar Ali Shad ${ }^{1}$, Tariq Masood ${ }^{1 *}$, Zafar Ali Shah $^{1}$, Nasiruddin ${ }^{2}$, Yaseen Ahmad ${ }^{1}$ and Syed \\ Sartaj Alam ${ }^{3}$
}

${ }^{1}$ Department of Agricultural Chemistry and Biochemistry, The University of Agriculture, Peshawar, Pakistan; ${ }^{2}$ Directorate General Agricultural Research, Khyber Pakbtunkhwa, Peshawar, Pakistan; ${ }^{3}$ Department of Plant Pathology, The University of Agriculture, Peshawar, Khyber Pakhtunkhwa, Pakistan.

Abstract | Effect of substrate supplemented with a medicinal plant (Berberis lycium L) was documented on days to $50 \%$ colonization, days to $100 \%$ colonization, yield per bag and \% bio-efficacy of Pleurotus eryngii. It was found that maximum 20 and 34 days were taken by $50 \%$ and $100 \%$ colonization, respectively on $25 \%$ supplemented B. lycium substrate compared to control treatment (17 days). The yield and bio-efficacy of mushroom was observed around $596.7 \mathrm{~g}$ per bag and $99 \%$ respectively at $25 \%$ supplemented B. lycium substrate. The $P$. eryngii mass was extracted with different solvents and showed promising results for the number of phytochemicals. Alkaloids were present in all fractions except $n$-hexane and petroleum ether while tannins were present in all the fractions. Flavonoids, lipids, terpenoids and glycosides were present in extracts at moderate to high concentrations. Methanolic fraction of mushroom proved to be bactericidal with highest $\%$ inhibition $(65,36$ and $75 \%$ ) recorded at $25 \mathrm{mg} / \mathrm{L}$ concentration against all the three bacterial strains i.e., E. coli, Staphylococcus aureus and Xanthomonas sp., respectively. Maximum \% inhibition (about 50\%) was recorded at $25 \mathrm{mg} / \mathrm{L}$ concentration against all the three fungal species (Penicillium claviforme, Aspergillus flavus and Fusarium sp.). Methanolic extract of P. eryngii showed increasing \% mortality against red flour beetle (Tribolium castaneum) in methanolic extract with increasing concentration after 24 and 48 h exposure time. Maximum mortality (100\%) was noticed at $300 \mathrm{mg} / \mathrm{L}$ after $40 \mathrm{~h}$ exposure time. Hence, methanolic extract of $P$. eryngii can be used as a natural pesticide, especially in stored grains.

Received | February 08, 2021; Accepted | June 21, 2021; Published | August 17, 2021

*Correspondence | Tariq Masood, Department of Agricultural Chemistry and Biochemistry, The University of Agriculture, Peshawar, Pakistan;

Email: tariqafridi@aup.edu.pk

Citation | Sabir, S., A.A. Shad, T. Masood, Z.A. Shah, Nasiruddin, Y. Ahmad and S.S. Alam. 2021. The biocidal investigation of various extracts of Pleurotus eryngii cultivated on a substrate supplemented with Berberis lyceum. Sarbad Journal of Agriculture, 37(4): $1144-1155$.

DOI | https://dx.doi.org/10.17582/journal.sja/2021/37.4.1144.1155

Keywords | Pleurotus eryngii, Medicinal plant, Berberis Lycium, Biocidal activities, Substrate supplementation

\section{Introduction}

Synthetic chemicals are commonly used to control agricultural pests and plant pathogens in every part of the world (Whipps and Lumsden, 2001). Worldwide loss in crop production is currently 15 $\%$ due to pests (Maxmen, 2013). To overcome this, a large amount of pesticide is used. It is clear that these chemicals are persistent in the environment and their residues can end up in our food chain (Montesinos, 2003). Uncontrolled use of these chemicals results in resistance to pesticides, toxicity to humans, animals, and plants and is thus deemed environmentally unacceptable (Bhattacharjee and Dey, 2014). This situation led scientists to look for new antimicrobial substances from different sources to be used as novel 
chemotherapeutic antimicrobial agents (Turkoglu et al., 2006). While searching for a new antimicrobial drug, the scientific community has found various therapeutic activities in different mushrooms. In recent decades, scientists are interested in evaluating mushrooms and plants for their natural products (Aziz et al., 2007). Many compounds with antibacterial potential are isolated from mushrooms, but only fungal antimicrobial compounds are commercially available in the market (Wong et al., 2009).

The fruiting bodies of higher fungi are called Basidiomycetes. Wild Basidiomycetes are good sources of several compounds with antibacterial, antiviral, antifungal, and insecticidal and nematicidal properties (Kolundžić et al., 2016; Santos et al., 2015). Basidiomycetes have proved helpful in the last few years due to their therapeutic values, less side effects on non-target organisms, and abundance availability (Jo et al., 2014). Among the reported 140,000 species of Basidiomycetes, about 660 species have medicinal value. For the survival of macrofungi in their natural habitat, they need antibacterial and antifungal compounds which they accumulate in their bodies. Therefore, several compounds with antimicrobial properties could be recovered from mushrooms and benefit plants, animals and humans (Wasser, 2008). Many bioactive compounds can be isolated from a single macrofungi with many pharmacological effects (Rathore et al., 2017). Although mushrooms have many antimicrobial compounds, the antimicrobial compounds from microscopic fungi still dominate as antibiotics.

The second most consumed mushrooms all over the world are from the Pleurotus genus. In the class of basidiomycetes, Pleurotus spp is sometimes known as "white rot fungi" (Tsujiyama and Ueno, 2013) due to the production of white mycelium and is typically grown on non-composted dead wood, lignin and cellulosic substrates. Different forms of Pleurotus, including $P$. eryngii (king oysters), P. pulmonarius (phanix mushrooms), P. ostreatus (oyster mushrooms), P. cystidiosus (abalone oysters), P. djamor (pink oysters), $P$. citrinopieatus (golden oysters) and $P$. cornucopiae, are grown commercially and have considerable economic value. A short period is required for Pleurotus spp to grow as compared to other mushrooms. It is an edible mushroom with high therapeutic value due to critical bioactive molecules (Yang et al., 2013). Numbers of variables either function independently or have combine impacts on mushroom survival and propagation. Chemical composition, carbon to nitrogen ratio, moisture, surfactant, nitrogen sources, minerals, water activity, $\mathrm{pH}$, inoculum quantity, antimicrobial agents in the environment, and competitive microorganisms are considered to affect mushrooms' development (Bellettini et al., 2019).

The chemical, functional and sensorial properties of mushrooms are also affected by substrates used in the production of mushrooms (Oyetayo and Ariyo, 2013). Pleurotus sp. is saprophytic and extracts its nutrients such as carbon, nitrogen, vitamins and minerals essential for its growth from the substrate such as grasses, wood and agricultural residues through mycelium. According to Mukhopadhyay et al. (2002), nutrient type and growth conditions are closely linked with fungus growth and development, both in quality and quantity aspects (biological productivity and efficiency). In a study, Michael et al. (2011) found that mushrooms grown on bean straw had more protein, ash, iron, and phosphorus content than mushrooms cultivated on wheat straw.

John Forbes Royle described Berberis lycium for the first time in 1837. Berberidaceae is a family of angiosperms containing around 12 genera and 600 species. B. lycium is native to Pakistan, Nepal, India and globally distributed in temperate and subtropical regions (apart from Australia). Berberine, chinabine, karakoramine, palmatine, gilgitine, jhelumine, punjabine, sindamine, chinabine acetic acid, maleic acid, ascorbic acid are the different chemical constituents of B. lycium (Khare, 2004) that impart medicinal value to this plant (Gupta et al., 2015). The fine powder of this medicinal plant was mixed with the mushroom substrate, its effect on the growth and yield of mushroom was studied. Further, the effectiveness of substrate supplemented with a medicinal plant (B. lycium) was investigated by in vitro experiments to know the biopharmaceutical potential of $P$. eryngii mushrooms.

\section{Materials and Methods}

The research work was carried out in various laboratories of The University of Agriculture Peshawar. All chemicals and reagents used in this experiment were of analytical grade, whereas crude extracts and their various fractions were carried out through commercial grade solvents. 
Pure culture collection and preparation

Pleurotus eryngii was obtained from the Department of Plant Pathology, The University of Agriculture, Peshawar. It was inoculated on Malt extract agar to obtain a pure culture. The resultant pure culture was maintained at $-10^{\circ} \mathrm{C}$ for around $25-30$ days. The next step of sub-culturing was inoculated onto a fresh slant of Malt extract agar within a month. In this experiment, malt extract in Agar (MEA) was used as a medium to grow pure culture. Approximately one liter of culture was made using $20 \mathrm{~g}$ Malt, $20 \mathrm{~g}$ dextrose and $20 \mathrm{~g}$ of Agar with $1 \mathrm{~g}$ of peptone. The volume was made with distilled water to one litre. This culture solution was autoclaved for half an hour at $15 \mathrm{psi}$ and $\mathrm{pH}$ was maintained at about 6.5 during the whole process. After sterilization, streptomycin was added to one litre solution at the rate of $1 \mathrm{~g} / \mathrm{L}$ while keeping the temperature at $40^{\circ} \mathrm{C}$ to avoid any bacterial contamination. To make inoculation successful small pieces of mushroom tissue were cut from the cap to downwards in the laminar flow unit with the help of a sterile blade and fruiting bodies were taken out into the Petri dish. Petri plates were sealed with parafilm and incubated at $25^{\circ} \mathrm{C}$. White mycelia started appearing on the surface of agar after 3-4 days. After becoming fully covered, petri plates were stored in the refrigerator to avoid any contamination or wastage during spawn preparation.

\section{Preparation of substrates}

Sawdust from the hardwood plant was thoroughly mixed with $2 \%$ chalk powder, $4 \%$ gypsum and $4 \%$ wheat bran on a dry weight basis. Water was added to the mixture to adjust the final moisture to $60-70 \%$. The $\mathrm{pH}$ of the substrate, as mentioned above, was adjusted to approximately 8.0. Afterward, B. lycium in the form of dried powder was added and thoroughly mixed with the substrate. The substrate was covered with polythene bags, piled up and allowed to ferment for hours and later spread on the floor to evaporate excess moisture. The details of the concentration of medicinal plant (treatments) in the substrates are explained in Table 1.

\section{Preparation of sample}

Fresh and fleshy mushrooms were harvested and stored in a clean dry place. When a sufficient quantity of mushrooms is obtained, they were dried under shade to complete dryness. It usually has been experienced that the complete dryness was achieved within a week time. The dried samples were ground by using an electrical grinder (Yigan, Model WF130).

Powdered samples were store in clean polythene bags with proper labels and stored in the refrigerator at $4^{\circ} \mathrm{C}$ until required for analysis.

\section{Extraction and fractionation}

Powdered mushroom samples were extracted with 90\% methanol and then fractionated with increasing polarity solvents ( $n$-hexane, petroleum ether, ethyl acetate, chloroform, butanol and water). The resultant fractions were dried by removing solvent using a vacuum rotary evaporator under a controlled temperature.

\section{Phytochemical screening}

Qualitative phytochemical screening was performed for alkaloids, carbohydrates, phytosterols, saponins, lipids, sterols, glycosides, terpenoids, tannins and flavonoids following the methods as described by Rahman et al. (2013).

\section{Biocidal activities}

Antimicrobial assay: Standard Disc diffusion method (Tassou et al.,2000) was carried out for an antibacterial test to evaluate the presence of antibacterial activities of methanolic extract of $P$. eryngii mushroom. In this method, cultures prepared from microbial inocula were placed on nutrient agar media plates. Using sterile forceps, the Whatman No. 1 filter paper disc (6 $\mathrm{m}$ diameter) was placed in the medium. Methanolic extract of mushroom dissolved in dimethyl sulfoxide (DMSO) at three different concentrations $(10,15$ and $\left.25 \mathrm{mg} \mathrm{L}^{-1}\right)$ were applied to the discs. Five discs per plate were taken; one for standard (Positive control), the second for DMSO (negative control) and the last three for three concentrations of methanolic crude extract. The zone of inhibition was measured in $\mathrm{mm}$ after 24 hours against three bacterial strains (E. coli, Staphylococcus aureus and Xanthomonas Sp.) and after one week against the three fungal strains (Penicillium claviforme, Aspergillus flavus and Fusarium Sp). Percent inhibition for each concentration of methanolic extract against the bacterial strains and fungal strains were calculated by using the formula:

$$
\% \text { Inhibition }=\frac{\text { Zone of Inhibition for extract }}{\text { Zone of Inhibition for standard }} \times 100
$$

Nematicidal assay: Nematodes were removed from soil using Cobb's method (Cobb, 1986). The method employs variations in shape, size, and sedimentation 
rate between nematodes and soil particles and mobility of nematodes.

\section{Exaction of nematode}

Soil weighing 50 gm was taken in a beaker containing one $\mathrm{L}$ of water. Homogenous soil water mixture was obtained by stirring. The mixture was kept for fifteen seconds and the material was decanted into another tub. This step was repeated three times. The sediment collected in the beaker was discarded. The suspension was moved from the plastic bowl to a new bowl via 500, 350, 175, 100 and 45 um sieves. The sieve with the mixture was shacked to facilitate nematodes to go out. The waste left over was discarded on the 500 and $100 \mu \mathrm{m}$ sieve. But the debris was washed and collected from the $45 \mu \mathrm{m}$ sieve in a 'collecting pan'. Two nematode filters were attached with a clamping ring in the extraction sieve. They were moistened to get rid of air bubbles between the two filter papers. The sieve was put in a water-filled decanting tray. The suspension was poured out onto the filter paper from the collecting pan. Maximum water was applied to the decantation tray to hold filter paper wet $( \pm 100$ $\mathrm{ml})$. The tray was sealed to avoid evaporation and dust contamination. The sieve was removed after 16-48 hours the nematodes were poured into a beaker for analysis.

Procedure: Zero (negative control with DMSO), 100, 200 and $300 \mu \mathrm{g} \mathrm{mL} \mathrm{m}^{-1}$ concentrations of extract made in three different organic solvents (methanol, ethyl acetate and butanol) were poured from the stock solution. Nematodes (40 in number) were poured from suspension in cavity blocks with the aid of a counting chamber. Every treatment was performed in triplicate. The mortality of nematode was studied after 24 and 48 hours under a microscope.

Insecticidal assay: The film residue method (Busvine, 1971) was used to test the mortality of red flour beetle (Tribolium castaneum) against different concentrations of methanolic extract of $P$ eryngii cultivated on $B$. lycium rich substrate after 24 and 40 hours of period exposure.

Procedure: Adult insects were obtained from the Department of Entomology, the University of Agriculture Peshawar. Three different concentrations of methanolic extract of mushroom along with positive (dimethyl sulphoxide) and negative control (Permethrin@240ug/ $\mathrm{cm}^{2}$ ) were used. The stock solution of $1000 \mu \mathrm{g} \mathrm{ml}^{-1}$ was prepared by dissolving $2 \mathrm{mg}$ crude methanolic extract in $2 \mathrm{ml}$ of dimethyl sulphoxide. Three concentrations of 100, 200 and $300 \mathrm{mg} \mathrm{L}{ }^{1}$ respectively were prepared from the stock solutions. Two to five repetitions were used for each concentration along with control treatments. Two $\mathrm{ml}$ of each concentration of the extract and control samples were applied to the glass vessels. Each vessel was manually rotated until the test solution was distributed equally on the interior wall and floor of the vessel. All the vessels were kept in a fume hood for complete evaporation of carrier solvent (DMSO). After the solvent evaporation, five test insects were carefully placed in each glass vessel with sufficient feed. Insect's survival was evaluated after 24 and 40-hours exposure time. According to Abbott's formula, the mortality rate calculation was corrected for control mortality (Abbott, 1925).

$$
M c=(M o-M c / 100-M e) \times 100
$$

Where $\mathrm{Mo}=$ Observed mortality rate of treated adults (\%), $\mathrm{Me}=$ mortality rate of control (\%), and $\mathrm{Mc}=$ corrected mortality rate (\%).

\section{Statistical analysis}

Data were analysed by using a completely randomized design. In addition, the least significance difference (LSD) test was applied for separating significantly different means. Means and standard deviations were also calculated to determine the activity of different concentrations (Steel and Torrie, 1980).

\section{Results and Discussion}

Both wild and cultivated mushrooms played an attractive role as a functional food and therapeutic agent since the $18^{\text {th }}$ century and recently increased many folds. They are now cultivated in many developed and developing countries for their taste, nutritional, medicinal properties and nutraceutical agents in industries (Lim et al., 2004). Several research articles mentioned the characterization of several hundred phytotoxins and their role in preventing various pathogenic pests both in plants and animals. The dried powdered, curd extracts and natural products isolated from certain fungi played a vital role in the modern agriculture pest management system. Various fungi are investigated for biological pest control insects, including fleas, ticks, mites, worms and nematodes in many parts of the world. 
Table 1: Experimental treatment detail.

$\begin{array}{lllllll}\begin{array}{l}\text { Treat- } \\ \text { ments }\end{array} & \begin{array}{l}\text { Amount of } \\ \text { sawdust (g) }\end{array} & \begin{array}{l}\text { Amount of Med. } \\ \text { plant (g) used }\end{array} & \begin{array}{l}\text { \% Med. plant used } \\ \text { (dry wt. base) }\end{array} & \begin{array}{l}\text { Number of Dry wt. per bag (g) } \\ \text { bags }\end{array} & \begin{array}{l}\text { Wet wt. per bag with } \\ \mathbf{6 0 \%} \text { moisture }\end{array} \\ \text { T1 } & 600 & 0 & 0 & 10 & 600 & 1500 \\ \text { T2 } & 590 & 10 & 1.66 & 10 & 600 & 1500 \\ \text { T3 } & 550 & 50 & 8.33 & 10 & 600 & 1500 \\ \text { T4 } & 500 & 100 & 16.66 & 10 & 600 & 1500 \\ \text { T5 } & 450 & 150 & 25 & 10 & 600 & 1500\end{array}$

Table 2: Effect of Berberis lycium as an amendment in saw dust used as substrate on the yield and yield components of P. eryngii.

$\begin{array}{llllll}\text { Treatments } & \text { Days to 50\% colonization } & \begin{array}{l}\text { Days to 100\% coloni- } \\ \text { zation }\end{array} & \begin{array}{l}\text { Days to pinhead } \\ \text { initiation }\end{array} & \text { Yield/bag (g) } & \begin{array}{l}\text { \% Bio. effi- } \\ \text { cacy }\end{array} \\ \text { T1 (Control) } & 17.3 \pm 1.2 \mathrm{~b} & 27.3 \pm 2.1 \mathrm{c} & 45.3 \pm 0.6 \mathrm{bc} & 503.3 \pm 25.2 \mathrm{~b} & 83.7 \pm 4.0 \mathrm{~b} \\ \text { T2 }(2 \% \mathrm{~m} \cdot \mathrm{p}) & 10.7 \pm 1.2 \mathrm{~d} & 25.7 \pm 0.6 \mathrm{~cd} & 41.7 \pm 0.6 \mathrm{~d} & 561.7 \pm 24.7 \mathrm{a} & 93.0 \pm 4.4 \mathrm{a} \\ \text { T3 }(8 \% \mathrm{~m} \cdot \mathrm{p}) & 12.7 \pm 1.2 \mathrm{c} & 24.3 \pm 0.6 \mathrm{~d} & 43.7 \pm 0.6 \mathrm{~cd} & 590.0 \pm 10.0 \mathrm{a} & 98.0 \pm 2.0 \mathrm{a} \\ \text { T4 }(17 \% \mathrm{~m} \cdot \mathrm{p}) & 17.3 \pm 0.6 \mathrm{~b} & 31.3 \pm 2.1 \mathrm{~b} & 46.3 \pm 1.5 \mathrm{ab} & 568.3 \pm 27.5 \mathrm{a} & 94.3 \pm 4.9 \mathrm{a} \\ \text { T5 }(25 \% \mathrm{~m} \cdot \mathrm{p}) & 20.0 \pm 0.0 \mathrm{a} & 34.7 \pm 0.6 \mathrm{a} & 48.3 \pm 1.5 \mathrm{a} & 596.7 \pm 25.2 \mathrm{a} & 99.0 \pm 3.6 \mathrm{a}\end{array}$

Mean $\pm S D$; Means followed by different letters in each column are significantly different at 0.05 level of significance, $m$. $p=$ medicinal plant.

Pleurotus eryngii cultivation on Berberis lycium rich substrate

The effect of $B$. lycium supplemented P. eryngii was investigated and found to influence the number and size of the fruit body. The details of the study are presented in Table 2 showing the primary cultivation characteristics. It was observed that a maximum level of $50 \%$ colonization (20 days) was achieved on $25 \%$ medicinal plant-rich substrate. Compared to the control group, the rest of $B$. lycium-rich substrate concentrations do not affect 50\% colonization of cultivated mushrooms. Similar results were observed for $100 \%$ colonization (34.7 days) on $25 \%$ B. lyciumrich substrate. The maximum yield and \% bio-efficacy of mushrooms were observed (596.7 $\mathrm{g}$ per bag and 99\% respectively) using $25 \%$ supplemented B. lycium substrate for growth. Present results confirmed that $B$. lycium supplemented substrate could be a vibrant way to enhance the production of $P$. eryngii mushroom. Predictably, bioactive compounds of these native mushrooms could be enhanced many folds if they prefer to grow on medicinal plant supplemented substrates. Literature confirmed that our native dietary and medicinal mushrooms are an appreciable source of proteins, vitamins and other bioactive compounds (Manzoor et al., 2019; Badshah et al., 2015).

Nevertheless, these valuable native mushrooms are rarely available, so the cultivation is increasing progressively in the recent decade. Further stress on the bioactive manipulated substrate could produce an important rich dietary and medicinal mushroom (Badshah et al., 2015). Very few studies have been conducted to justify the influence of supplemented substrates and levels that would give the best bioactive substances.

\section{Phytochemical screening}

Chemical screening of fresh harvested fruiting bodies of subject mushrooms cultivated on B. lycium rich substrate is tabulated in Table 3. Six fractions were obtained with increasing polarity including methanol, $n$-hexane, petroleum ether, ethyl acetate, chloroform, butanol and water. These fractions were investigated for the presence of different secondary metabolites viz. alkaloids, carbohydrates, flavonoids, terpenoids, glycosides, saponins, sterols and lipids. Present analysis exhibited that alkaloids were available in most fractions, including methanol, ethyl acetate, chloroform, butanol, and aqueous except $n$-hexane and petroleum ether. Saponins were found in methanol, butanol and water fractions of $P$. eryngii.

Further, it was revealed that tannins were not found in any solvent fraction of the extracted samples. The extracted samples are a moderate source of lipids and terpenoids in hexane, petroleum ether, ethyl acetate and chloroform fractions except for the aqueous fraction where it was found absent. Since bioactive compounds play a crucial role in the living 
organism and their importance has been discussed in many research articles in detail (Anjana et al., 2016). More than 50 dietary mushrooms and several hundred fungal species have natural products in a significant amount. The vital bioactive compounds like terpenoids, alkaloids, saponins, tannins are reported from various Pleurotus spp. responsible for antibacterial properties (Iwalokun et al., 2007). Several natural product chemistry studies oscillate that there may be an antagonistic and synergistic association among secondary metabolites and other compounds like proteins, carbohydrates, and certain elemental compounds that render such compounds' absorption.

Antibacterial potential of $P$. eryngii cultivated on $B$. lycium rich substrate

The $P$. eryngii cultivated on $B$. lycium rich substrate was extracted with methanol and further diluted with a solvent to get three different concentrations of the crude extract $\left(10,15\right.$ and $\left.25 \mathrm{mg} \mathrm{L}^{-1}\right)$. The antibacterial investigation of three concentrations was calculated compared to standard antibacterial drug streptomycin and presented in Table 4. The crude methanol fraction of the subject mushroom revealed that maximum activity against Xanthomonas sp. observed at 25 and $15 \mathrm{mg} \mathrm{L}^{-1}$ concentration were $30 \pm 1.5 \mathrm{~mm}$ and $25 \pm 1.7 \mathrm{~mm}$, respectively. The results exhibited activity of $7 \pm 1.5$ and $9 \pm 1.0$ against $S$. aureus at a concentration of 25 and $15 \mathrm{mg} \mathrm{L}^{-1}$, respectively. Likewise, the various samples based on the concentration of examined mushroom revealed that at $25 \mathrm{mg} \mathrm{L}^{-1}$ concentration, the antibacterial activity against $E$. coli was maximum $13 \pm 2.1 \mathrm{~mm}$ followed by $15 \mathrm{mg} \mathrm{L^{-1 }}$ concentration $(7 \pm 1.5 \mathrm{~mm})$. The overall results showed no activity was detected at $10 \mathrm{mg} \mathrm{L} \mathrm{L}^{-1}$ concentration against all the examined bacterial species. The concentration at $25 \mathrm{mgL}^{-1}$ showed 75, 65 and 36\% inhibition against Xanthomonas sp., E. coli and Staphylococcus aureus, respectively compared to streptomycin (Standard antibacterial drug). Likewise, at $15 \mathrm{mg} \mathrm{L}^{-1}$ concentration among the three concentrations used against selected bacterial species showed 62.5, 40 and $28 \%$ zone of inhibition against Xanthomonas sp., E. coli and Staphylococcus aureus, respectively as compared to the streptomycin.

Table 3: Phytochemical Screening of various fractions of P. eryngii cultivated on B. lycium rich substrate in the standard conditions.

\begin{tabular}{|c|c|c|c|c|c|c|c|}
\hline Phytochemicals & Crude extract & n-hexane & P. Ether & EtOAc & $\mathrm{CHCl}_{3}$ & Butanol & Aqueous \\
\hline Alkaloids & ++ & - & - & + & + & + & + \\
\hline Carbohydrates & + & - & - & - & - & + & + \\
\hline Saponins & + & - & - & - & - & ++ & + \\
\hline Lipids & ++ & ++ & ++ & + & ++ & + & - \\
\hline Sterols & + & + & + & + & ++ & ++ & + \\
\hline Glycosides & + & ++ & + & - & ++ & + & - \\
\hline Terpenoids & ++ & ++ & ++ & + & ++ & + & - \\
\hline Tanins & - & - & - & - & - & - & - \\
\hline Flavonoids & ++ & - & - & - & - & + & ++ \\
\hline
\end{tabular}

++: highly present; +: Moderately present and -: Absent .

Table 4: Antibacterial potential of methanolic extract of P. eryngii cultivated on B. lycium rich substrate against three bacterial strains.

\begin{tabular}{|c|c|c|c|c|c|}
\hline $\begin{array}{l}\text { Bacterial } \\
\text { strains }\end{array}$ & $\begin{array}{l}\text { Concentration of methanolic } \\
\text { extract of P. eryngii }\left(\mathrm{mg} \mathrm{L}^{-1}\right)\end{array}$ & $\begin{array}{l}\text { Inhibitory } \\
\text { zone (mm) }\end{array}$ & $\begin{array}{l}\% \text { inhibition com- } \\
\text { pared to Standard }\end{array}$ & $\begin{array}{l}\text { Inhibitory zone of Standard } \\
\text { (streptomycin) }(\mathrm{mm})\end{array}$ & $\begin{array}{l}\text { Dimethyl Sulfox- } \\
\text { ide (DMSO) }\end{array}$ \\
\hline \multirow[t]{3}{*}{ E. coli } & 10 & ND & 0 & \multirow[t]{3}{*}{20} & \multirow[t]{3}{*}{ ND } \\
\hline & 15 & $8 \pm 1.5$ & 40 & & \\
\hline & 25 & $13 \pm 2.1$ & 65 & & \\
\hline \multirow{3}{*}{$\begin{array}{l}\text { Staphy- } \\
\text { lococcus } \\
\text { aureus }\end{array}$} & 10 & ND & 0 & \multirow[t]{3}{*}{25} & \multirow[t]{3}{*}{ ND } \\
\hline & 15 & $7 \pm 1.5$ & 28 & & \\
\hline & 25 & $9 \pm 1.0$ & 36 & & \\
\hline \multirow{3}{*}{$\begin{array}{l}\text { Xanthomo- } \\
\text { nas Sp. }\end{array}$} & 10 & ND & 0 & \multirow[t]{3}{*}{40} & \multirow[t]{3}{*}{ ND } \\
\hline & 15 & $25 \pm 1.7$ & 62.5 & & \\
\hline & 25 & $30 \pm 1.5$ & 75 & & \\
\hline
\end{tabular}

ND: Not Detected; Mean \pm standard Deviation. 
Antimicrobial agents are compounds produced by bacteria, fungi, or synthetic in nature that kill microorganisms or inhibit their growth. They are widely employed to cure bacterial diseases. Similar results were obtained by Akyuz and Kirbag (2009) who evaluated the antimicrobial potential of methanolic extracts of $P$. eryngii grown on various agro-waste and noticed 7.7-10.3 mm zone of inhibition against different bacterial strains. Iwalokun et al. (2007) found good antimicrobial activity in petroleum ether extract of Pleurotus ostreatus ranging from 3-7.8 mm for gram-positive and 5-8.2 $\mathrm{mm}$ for gram-negative bacteria. The differences in results might be due to different quantities of phenols and terpenoids present, variations in strains and species, the difference in microbicidal concentration and composition and extraction method. Rehman et al. (2013) evaluated Pleurotus florida extract against different bacterial strains and found inhibition in the range of 9.20 to $17.0 \mathrm{~mm}$ within the zone of inhibition observed in the present study (8-13mm). Many researchers carried out antibacterial studies on different species of Pleurotus mushroom and concluded that methanolic and ethanolic extracts of mushroom showed maximum zone of inhibition against different bacterial strains (Mondal et al., 2013; Thillaimaharani et al., 2013). Significant antimicrobial potential in the methanolic extract is observed due to phenolic compounds and other secondary metabolites (Adebayo et al., 2012).

\section{Antifungal activity of $P$. eryngii cultivated on B. lycium} rich substrate

The effect of methanolic extract of $P$. eryngii in three different concentrations $\left(10,15\right.$ and $\left.25 \mathrm{mg} \mathrm{L}^{-1}\right)$ on three different fungal strains are shown in Table 5. Percent inhibition was increased with increasing concentration of extract. The highest \% inhibition was recorded at a concentration of $25 \mathrm{mg} \mathrm{L}^{-1}$ against all three fungal strains. Fusarium spp. was the most susceptible fungus among the selected fungi to all three concentrations of methanolic extract. Aspergillus flavus showed response to only $25 \mathrm{mg}$ $\mathrm{L}^{-1}$ concentration of methanolic extract of $P$. eryngii with the Second highest \% zone of inhibition (50\%) compared to standard antifungal used.

The antifungal activity of $P$. eryngii in the present experiment remained low (3.54-6.08 $\mathrm{mm}$ zone of inhibition) as compared to an earlier published report (Akuz and Kirbag, 2009) where they used methanolic extract of $P$. eryngii var. ferulae against different fungal strains and recorded 7.7-9.3 $\mathrm{mm}$ zone of inhibition. It is evident that the antimicrobial activity of $P$. eryngii (in study $3.44-6.08 \mathrm{~mm}$ ) are changeable as reported (4.0-29.0 $\mathrm{mm}$ ) by other researchers (Solak et al., 2006; Turkoglu et al., 2006; Barros et al., 2007). This may be due to the presence of different phytochemicals compounds in different species of $P$. eryngii mushroom and the use of different solvents and test microorganisms (Akuz and Kirbag, 2009).

\section{Insecticidal activity of $P$. eryngii cultivated on B. lycium} rich substrate

There is a growing trend in the search for harmless insecticides for the environment or as synthetic ones that are considered more toxic to the environment (Pavela, 2004). In the present study, we considered the insecticidal activity of mushroom extract using T. castaneum (red flour beetle) as a test insect. The methanolic extract of P. eryngii at 100, 200 and 300 $\mathrm{mg} \mathrm{L} \mathrm{L}^{-1}$ was used against T. castaneum and the results were collected as a percentage of mortality (Table 6). The metabolic extract of $P$. eryngii exhibited 10,10 and $70 \%$ mortality at 100,200 and $300 \mathrm{mgL}^{-1}$, respectively, after 24 hours of inspection under similar conditions. The experiment duration was increased to 40 hours with similar concentrations $\left(100,200,300 \mathrm{mg} \mathrm{L}^{-1}\right)$ and conditions to confirm insect mortality behavior. It was examined that 40, 80 and $100 \%$ mortality was noticed with a prolonged exposure time up to 40 hours with similar conditions. The current findings reveal that King Oyster Mushroom (P. eryngii) is effective against infestation by $T$. castaneum and can function as an excellent natural pesticide for stored grain pests.

Literatures studies divulge that the secondary metabolites isolated from various Basidiomycetes have been known to show antibacterial properties (Rosa et al., 2003). Basidiomycetes provide an effective and low-cost product for the control of plant and human diseases. Rehman et al. (2013) showed in their experiment that the toxicity of the extracts and fractions of the oyster mushroom (Pleurotus ostreatus) increased with the increase of the exposure time. This can support that exposure time plays an essential role in the influence of susceptibility. Similarly, Bucker et al. (2013) reported high larvicidal activity against Aedes aegypti and Anopheles nuneztovari mosquitoes using crude extracts of different basidiomycetes, especially Pycnoporus sanguineus,. The extract showed a significant potential for producing bioactive substances against the larvae of these two vectors of 
tropical diseases. According to Chelela et al. (2014), respectively. It has been shown that the extracts of the crude ethanol extract of Lactarius gymnocarpoides numerous fruiting bodies of fungi possess insecticidal exhibited the highest larvicidal activity against the properties, and several of these fungi are edible, A. aegypti mosquito, with an LC50 of $10.75 \mu \mathrm{g} / \mathrm{mL}$ which makes them valuable sources of new candidate after $72 \mathrm{~h}$ of exposure. The chloroform extract of $L$. insecticides. The insecticidal properties of these densifolius was effective against Anopheles gambiae fungi were attributed to proteins such as lectins or (LC50= $91.33 \mu \mathrm{g} / \mathrm{mL}$ ) and moderately effective hemolysins (Wang et al., 2002). against Culex quinquefasciatus (LC50=181.16 $\mu \mathrm{g} / \mathrm{mL}$ ),

Table 5: Effect of methanolic extract of P. eryngii cultivated on B. lycium rich substrate against three fungal strains.

\begin{tabular}{|c|c|c|c|c|c|}
\hline Fungal strains & $\begin{array}{l}\text { Concentration of } P \text {. } \\
\text { eryngii }\left(\mathrm{mg} \mathrm{L}^{-1}\right)\end{array}$ & $\begin{array}{l}\text { Inhibitory zone } \\
(\mathrm{mm})\end{array}$ & $\begin{array}{l}\text { \% inhibition com- } \\
\text { pared to Standard }\end{array}$ & $\begin{array}{l}\text { Inhibitory zone of standard } \\
\text { (Acrobat) }(\mathrm{mm})\end{array}$ & $\begin{array}{l}\text { Dimethyl Sulfox- } \\
\text { ide (DMSO) }\end{array}$ \\
\hline \multirow{3}{*}{$\begin{array}{l}\text { Penicillium clav- } \\
\text { iform }\end{array}$} & 10 & $3.54 \pm 1.0$ & 29 & \multirow[t]{3}{*}{12.08} & \multirow[t]{3}{*}{ ND } \\
\hline & 15 & $4.05 \pm 1.3$ & 34 & & \\
\hline & 25 & $6.08 \pm 1.5$ & 50 & & \\
\hline \multirow[t]{3}{*}{ Aspergillus flavus } & 10 & ND & ND & \multirow[t]{3}{*}{10.61} & \multirow[t]{3}{*}{ ND } \\
\hline & 15 & ND & ND & & \\
\hline & 25 & $5.33 \pm 1.0$ & 50 & & \\
\hline \multirow[t]{3}{*}{ Fusarium sp. } & 10 & $4.06 \pm 1.2$ & 41 & \multirow[t]{3}{*}{9.87} & \multirow[t]{3}{*}{ ND } \\
\hline & 15 & $4.81 \pm 1.3$ & 49 & & \\
\hline & 25 & $5.03 \pm 1.5$ & 51 & & \\
\hline
\end{tabular}

ND: Not Detected; Mean \pm standard Deviation.

Table 6: Insecticidal activity of methanolic extract of P. eryngii cultivated on B. lycium rich substrate against Red flour beetle (T. castaneum) exposure after two times intervals.

\begin{tabular}{|c|c|c|c|c|c|c|c|}
\hline \multirow[t]{3}{*}{ Sample } & \multirow{3}{*}{$\begin{array}{l}\text { Concentration (mg } \\
\left.\mathrm{L}^{-1}\right)\end{array}$} & \multicolumn{3}{|c|}{ Insecticidal activity after 24 hours } & \multicolumn{3}{|c|}{ Insecticidal activity after $\mathbf{4 0}$ hours } \\
\hline & & \multicolumn{6}{|c|}{ Tribolium castaneum } \\
\hline & & No. of survivors & No. of died & $\%$ Mortality & No. of survivors & No. of died & \% Mortality \\
\hline P. eryngii & $\begin{array}{l}100 \\
200 \\
300\end{array}$ & $\begin{array}{l}09 \\
09 \\
03\end{array}$ & $\begin{array}{l}1 \\
1 \\
07\end{array}$ & $\begin{array}{l}10 \\
10 \\
70\end{array}$ & $\begin{array}{l}06 \\
02 \\
0\end{array}$ & $\begin{array}{l}04 \\
08 \\
10\end{array}$ & $\begin{array}{l}40 \\
80 \\
100\end{array}$ \\
\hline Negative control & 100 & 09 & 01 & 10 & 08 & 02 & 20 \\
\hline Positive control & 100 & 0 & 10 & 100 & 0 & 10 & 100 \\
\hline
\end{tabular}

Positive control= dimethyl sulphoxide; Negative control= Permethrin

Table 7: Nematicidal activity of P. eryngii against Root Knot Nematode (Meloidogyne incognita) exposure after two times intervals.

\begin{tabular}{|c|c|c|c|c|c|c|c|}
\hline \multirow{3}{*}{$\begin{array}{l}\text { Extract of Pleuro- } \\
\text { tus eryngii }\end{array}$} & \multirow{3}{*}{$\begin{array}{l}\text { Concentra- } \\
\text { tion (ppm) }\end{array}$} & \multicolumn{3}{|c|}{ Nematicidal Activity after 24 hours } & \multicolumn{3}{|c|}{ Nematicidal Activity after 48 hours } \\
\hline & & \multicolumn{6}{|c|}{ Root Knot Nematode (M. incognita) } \\
\hline & & No. of survivors & No. of died & Mortality (\%) & No. of survivors & No. of died & Mortality (\%) \\
\hline \multirow[t]{3}{*}{ Methanol } & 100 & 39 & 11 & 22 & 29 & 21 & 42 \\
\hline & 200 & 36 & 14 & 28 & 23 & 27 & 54 \\
\hline & 300 & 33 & 17 & 34 & 19 & 31 & 62 \\
\hline \multirow[t]{3}{*}{ Ethyl Acetate } & 100 & 41 & 9 & 18 & 33 & 17 & 4 \\
\hline & 200 & 32 & 18 & 36 & 25 & 25 & 50 \\
\hline & 300 & 28 & 22 & 44 & 21 & 29 & 58 \\
\hline \multirow[t]{3}{*}{ Butanol } & 100 & 46 & 4 & 8 & 35 & 15 & 30 \\
\hline & 200 & 41 & 9 & 18 & 29 & 21 & 42 \\
\hline & 300 & 37 & 13 & 26 & 23 & 27 & 54 \\
\hline Control (DMSO) & & 47 & 3 & 6 & 47 & 3 & 6 \\
\hline
\end{tabular}


Nematicidal activity of $P$. eryngii cultivated on B. lycium rich substrate

Nematodes are great curses that damage agriculture yield significantly including fruits, vegetables, plants, animals and microorganisms. Agricultural foods and native biodiversity in forests susceptible to nematode infections cause severe damage to agriculture and forestry. It has been reported that plant root-knot nematodes (RKNS) are responsible for millions of dollars damages to agriculture sectors. This is the reason that the scientific community mainly focuses on working on this critical area. The objective of this study was to investigate the effect of crude fractions of methanol, ethyl acetate and Butanol with three different concentrations $\left(100,200\right.$ and $300 \mathrm{mg} \mathrm{L}^{-1}$ ) of P. eryngii cultivated on $B$. lycium rich substrate on root-knot nematode (Meloidogyne incognita). Mortality percentage of nematodes ( $M$. incognita) exposed to selected concentrations of subject mushroom were recorded and tabulated in Table-7. Results revealed that all the selected concentrations exhibited an excellent level of mortality at two different time intervals (24 and 48 hours). All the three solvent fractions at $300 \mathrm{mg} \mathrm{L} \mathrm{L}^{-1}$ concentration had higher mortality rates after $48 \mathrm{~h}$ exposure time as compared to $24 \mathrm{~h}$. Methanolic extract showed $34 \%$ mortality after 24 h exposure time raised to $62 \%$ over $48 \mathrm{~h}$ exposure time. It was observed that the highest mortality percentage achieved from methanol extract (62\% after $48 \mathrm{~h}$ exposure time) among all the examined solvent extracts of $P$. eryngii followed by ethyl acetate extract (58\% after 48 $\mathrm{h}$ exposure time) at the maximum concentration (300 $\left.\mathrm{mg} \mathrm{L}^{-1}\right)$. However, during the experimental investigation, it was observed that butanol extract had lower mortality levels of adolescent and adult nematodes (26 and 54\%) after intervals of 24 and $48 \mathrm{~h}$ of exposure time respectively. A similar result was reported by Elbadri et al. (2008) where they observed that mortality rates of nematodes increased with an increase in exposure time. Several reports on high mortality of RKNs by using different aqueous extracts of neem formulations (Javed et al., 2008). Likewise, extracts of C. coronarium plants had nematostatic activity against several life-stages (egg-masses, separated eggs and J2) of RKNs and the effect was irreversible (Bar-Eyal et al., 2006).

\section{Conclusions and Recommendations}

The present study concluded that B. lycium supplemented substrate could be a vibrant way to enhance the production of $P$. eryngii mushroom with high number of bioactive compounds especially terpenoids, alkaloids, flavonoids and sterols. Moreover, some other medicinal plants which are not in human use can be supplemented with the substrate for different Pleurotus mushrooms to check its effect on yield and biological efficacy.

\section{Novelty Statement}

The research dealt with the enhancement in growth and phytochemical potential of $P$. eryngii mushroom by substrate amendment with $B$. lycium. This amendment in substrate substantially increased the growth and bioactive potential of the mushroom.

\section{Author's Contribution}

Shahida Sabir and Yaseen Ahmad have carried out experimental work. Syed Sartaj Alam and Faizan helped in the field experiment of mushroom cultivation. Anwar Ali Shad and Tariq Masood have supervised the study. Zafar Ali Shah and Nasiruddin contributed to the data analysis and proofreading of the manuscript.

\section{Conflict of interest}

The authors have declared no conflict of interest.

\section{References}

Abbott, W.S. 1925. A method of computing the effectiveness of an insecticide. J. Econ. Ent. 18: 265-267. https://doi.org/10.1093/ jee/18.2.265a

Adebayo, E.A., J.K. Oloke, A.A. Ayandele and C.O. Adegunlola. 2012. Phytochemical, antioxidant and antimicrobial assay of mushroom metabolite from Pleurotus pulmonarious -LAU 09 (JF736658). J. Microbiol. Biotech. Res., 2(2): 366-374.

Akyuz, M. and S. Kirbag. 2009. Antimicrobial activity of Pleurotus eryngii var. ferulae grown on various agro-wastes. Eur. Asia J. Biol. Sci., 3: 5863. https://doi.org/10.5053/ejobios.2009.3.0.8

Anjana, S.K.G., T.S.B. Balamurugan, V. Manivasagan and N.G.R. Babu. 2016. Phytochemical, Antioxidant and Antitumor activity of edible mushroom Pleurotus ostreatus. Int. J. Adv. Res. Biol. Sci., 3(9): 170-177. https://doi. org/10.22192/ijarbs.2016.03.09.024 
Aziz, T., E.D. Mehmet and A.M. Nazime. 2007. Antioxidant and Antimicrobial Activity of Russula delica Fr: An Edi Wild Mus. Eur. J. Anal. Chem., 2: 64-67. https://doi.org/10.12973/ ejac/78055

Badshah, H., F. Ullah, M.U. Khan, A.S. Mumtaza and R.N. Malik. 2015. Pharmacological activities of selected wild mushrooms in South Waziristan (FATA), Pakistan. S. Afr. J. Bot., 97: 107-110. https://doi.org/10.1016/j. sajb.2014.12.002

Bar-Eyal, M., E. Sharon and Y. Spiegel. 2006. Nematicidal activity of Chrysanthemum coronarium. Eur. J. Plant Pathol., 114: 427-433. https:// doi.org/10.1007/s10658-006-0011-7

Barros, L., C.C. Ricardo, A.V. Josiana, C.F.R.I. Ferreira, P. Baptista and L.M. Estevinho. 2007. Antimicrobial activity and bioactive compounds of Portuguese wild edible mushrooms methanolic extracts. Eur. Food Res. Technol., 225: 151-156. https://doi.org/10.1007/s00217006-0394-x

Bauer, A.W., W.M.M. Kirby, J.C. Scherris and M. Turck. 1966. Antibiotic susceptibility testing by a standardized single disk method. Am. J. Clin. Pathol., 45: 493-496. https://doi.org/10.1093/ ajcp/45.4_ts.493

Bellitinni, M.B., F.A. Fiorda, H.A. Maieves, G.L. Teixeira, S. Ávila, P.S. Hornung, A.M. Júnior and R.H. Ribani. 2019. Factors affecting mushroom Pleurotus spp. Saudi J. Biol. Sci., 26(4): 633-646. https://doi.org/10.1016/j. sjbs.2016.12.005

Bhattacharjee, R. and U. Dey. 2014. An overview of fungal and bacterial biopesticides to control plant pathogens/diseases. Afr. J. Microbiol. Res., 8: 1749-1762. https://doi.org/10.5897/ AJMR2013.6356

Bucker, A., N.C. Bucker, A.Q. Souza, A.M. Gama, E. Rodrigues-Filho, F.M. Costa and W.P. Tadei. 2013. Larvicidal effects of endophytic and basidiomycete fungus extracts on Aedes and Anopheles larvae (Diptera, Culicidae). Rev. Soc. Bras. Med. Trop., 46: 411-419. https://doi. org/10.1590/0037-8682-0063-2013

Busvine, J.R. 1971. A critical review of the techniques for testing insecticides. Commonwealth Agricultural Bureau, London. pp. 345.

Chelela, B.L., M. Chacha and A. Matemu. 2014. Larvicidal potential of wild mushroom extracts against Culex quinquefasciatus. Am. J. Res. Com- mun., 2: 105-114.

Cobb, N.A. 1986. Estimating the nematode population of the soil. Agric. Tech. Circ. Bur. Pl. Ind. U.S. Dept. Agric., 1: 48.

Elbadri, G.A.A., D.W. Lee, J.C. Park, H.B. Yu and H.Y. Choo. 2008. Evaluation of various plant extracts for their nematicidal efficacies against juveniles of Meloidogyne incognita. J. Asia Pac. Entomol., 11: 99-102. https://doi. org/10.1016/j.aspen.2008.04.004

Gupta, M., S. Ajay and C.J. Harish. 2015. Berberis lycium multipotential medicinal application: An overview. Int. J. Chem. Stud., 3(4): 10-13.

Iwalokun, B.A., U.A. Usen, A.A. Otunba and D.K. Olukoya. 2007. Comparative phytochemical evaluation, antimicrobial and antioxidant properties of Pleurotus ostreatus. Afr. J. Biotechnol., 6(15): 1732-1739. https://doi. org/10.5897/AJB2007.000-2254

Javed, N., S.R. Gowen, S.A. El-Hassan, M. Inamul-Haq, F. Shahina and B. Pembroke. 2008. Efficacy of neem (Azadirachta indica) formulations on biology of root-knot nematodes (Meloidogyn ejavanica) on tomato. J. Crop Prot., 27: 36-43. https://doi.org/10.1016/j.cropro.2007.04.006

Jo, W.S., M.A. Hossain and S.C. Park. 2014. Toxicological profiles of poisonous, edible, and medicinal mushrooms. Mycobiology, 42: 215-220. https://doi.org/10.5941/ MYCO.2014.42.3.215

Khare, C.P. 2004. Indian herbal remedies, Springer, New York. pp. 98-100. https://doi. org/10.1007/978-3-642-18659-2

Kolundžić, M., N.D. Grozdanić, M. Dodevska, M. Milenković, F. Sisto, A. Miani, G. Farronato and T. Kundaković. 2016. Antibacterial and cytotoxic activities of wild mushroom Fomes fomentarius (L.) Fr., Polyporaceae. Ind. Crops. Prod., 79: 110-115. https://doi.org/10.1016/j. indcrop.2015.10.030

Lim, B.O., K. Yamada, B. Cho, T. Jeon, S.G. Hang, S.A. Kang and D.K. Park. 2004. Comparative study on the modulation of $\operatorname{IgE}$ and cytokine production by Phellinus linteus grown on germinated brown rice, Phellinus linteus and germinated brown rice in murine splenocytes.. Biosci. Biotechnol. Biochem., 68(11): 2391-2394. https://doi.org/10.1271/bbb.68.2391

Manzoor, M., M. Asrar., S.K. Leghari and Z. Ahmed. 2019. Nutritional value of wild mushrooms from Kharan district of Balochistan, $\mathrm{Pa}-$ 
kistan. FUUAST J. Biol., 9(2): 209-214.

Maxmen, A. 2013. Crop pests: Under attack. Nature, 501: S15-S17. https://doi.org/10.1038/ 501S15a

Michael, H.W., B.G. Geremew and L.M. Pant. 2011. Nutritional contents of three edible oyster mushrooms grown on two substrates at Haramaya, Ethiopia, and sensory properties of boiled mushroom and mushroom sauce. Int. J. Food Sci. Technol., 46(4): 732-738. https://doi. org/10.1111/j.1365-2621.2010.02543.x

Mondal, T., R. Some and S. Dutta. 2013. Studies on antioxidant and antimicrobial properties of some common mushrooms. J. Today's Biol. Sci. Res. Rev., (JTBSRR). 2: 60-67.

Montesinos, E. 2003. Development, registration and commercialization of microbial pesticides for plant protection. Int. Microbiol., 6:245-252. https://doi.org/10.1007/s10123-003-0144-x

Mukhopadhyay, R., B.P. Chatterjee and A.K. Guha. 2002. Biochemical changes during fermentation of edible mushroom Pleurotus sajorcaju in whey. Process Biochem., 38: 723-725. https:// doi.org/10.1016/S0032-9592(02)00192-9

Oyetayo, V.O. and O.O. Ariyo. 2013. Micro and macronutrient properties of Pleurotus ostreatus (Jacq:Fries) cultivated on different wood substrates. Jordan J. Biol. Sci., 6: 223-226. https:// doi.org/10.12816/0001537

Pavela, R. 2004. Insecticidal activity of certain medicinal plants. Fitoterapia, 75: 745-749. https:// doi.org/10.1016/j.fitote.2004.08.005

Rathore., H.S. Prasad and S. Sharma. 2017. Mushroom nutraceuticals for improved nutrition and better human health: A review. Pharm. Nutr., 5: 35-46. https://doi.org/10.1016/j.phanu.2017.02.001

Rehman, M.M., A. Rahaman, T. Nahar, B. Uddin, M.A. Basunia and S. Hossain. 2013. Antioxidant and Antimicrobial Activity of Pleurotus Florida Cultivated in Bangladesh. J. Med. Plants Stud., 1(3): 166-175.

Rosa, L.H., K.M.G. Machoda, C.C. Jacob, M. Capelari, C.A. Rosa and C.L. Zani. 2003. Screening of Brazilian basidiomycetes for antimicrobial activity. Memorias do Instituto Oswaldo Cruz Rio de Jenerio. 98: 967-974. https:// doi.org/10.1590/S0074-02762003000700019

Santos, D.N., L.L. de Souza, C.A. de Oliveira, E.R. Silva and A.L. de Oliveira. 2015. Arginase inhibition, antibacterial and antioxidant activities of Pitanga seed (Eugenia uniflora L.) extracts from sustainable technologies of high pressure extraction. Food Biosci., 12: 93-99. https://doi. org/10.1016/j.fbio.2015.09.001

Solak, M.H., E. Kalmis, H. Saglam and F. Kalyoncu. 2006. Antimicrobial activity of two wild mushrooms Clitocybe alexandri (Gill.) Konr. and Rbizopogon roseolus (Corda) T.M. Fries collected from Turkey. Phytother. Res., 20: 10851087. https://doi.org/10.1002/ptr.2002

Steel, R.G.D. and J.H. Torrie. 1980. Principles and Procedure of Statistics. A biometrical Approach. McGraw-Hill, New York.

Tassou, C.K. Koutsoumanis and J.G.J.E. Nychas. 2000. Inhibition of Salmonella enteritidis and Staphylococcus spaureus in nutrient broth by mint essential oil.Food Res.Int.,33:273-280.https:// doi.org/10.1016/S0963-9969(00)00047-8

Thillaimaharani, K.A., K. Sharmila, P. Thangaraju, M. Karthick and M. Kalaiselvam. 2013. Studies on antimicrobial and antioxidant properties of oyster mushroom Pleurotus florida. Int. J. Pharm. Sci. Res., 4(4): 1540-1545.

Tsujiyama, S. and H. Ueno. 2013. Performance of wood-rotting fungi-based enzymes on enzymic saccharification of rice straw. J. Sci. Food Agric., 93: 2841-2848. https://doi.org/10.1002/ jsfa. 6118

Turkoglu, A., I. Kivrak, N. Mercan, M.E. Duru, K. Gezer and H. Turkoglu. 2006. Antioxidant and antimicrobial activities of Morchella conica Pers. Afr. J. Biotech., 5: 1146-1150.

Wang, M., V. Triguéros, L. Paquereau, L. Chavant and D. Fournier. 2002. Proteins as Active Compounds Involved in Insecticidal Activity of Mushroom Fruitbodies. Source: J. Econ. Entomol., 95(3): 603-607. https://doi. org/10.1603/0022-0493-95.3.603

Wasser, S.P. 2008. A book review: The fungal pharmacy: Medicinal mushrooms of western Canada (Robert Rogers, 2006, Prairie Deva Press, Edmonton Alberta, 234 pp., Int. J. Med. Mushrooms, 10: 97-100. https://doi.org/10.1615/IntJMedMushr.v10.i1.130

Whipps, J.M. and R.D. Lumsden. 2001. Commercialuse of fungi as plant disease biological control agents: Status and prospects. In: Butt, T.M. and Jackson, C., editors. Fungal Biocontrol Agents: Progress, Problems and Potential. Volume 9. CABI Publishing; Oxfordshire, UK. pp. 9-22. https://doi.org/10.1079/9780851993560.0009 
Wong, K.H., S. Vikineswary, A. Noorlidah, R.K. Umah and N. Murali. 2009. Effects of Cultivation Techniques and Processing on Antimicrobial and Antioxidant Activities of Hericium erinaceus (Bull.:Fr.) Pers. Ext. Food Tech. Biot., 47: 47-55
Yang, Z., J. Xu., Q.Fu., X. Fu., T. Shu., Y. Bi., Y and B. Song. 2013. Antitumor activity of a polysaccharide from Pleurotus eryngii on mice bearing renal cancer. Carbohydr. Polym., 95: 615-620. https://doi.org/10.1016/j.carbpol.2013.03.024 